\title{
Mededinging
}

\section{Landbouwkartels en het mededingingsrecht: een nadere verduidelijking door het Hof van Justitie}

\author{
Mr. T.P.J.N. van Rijn*
}

Overeenkomsten tussen landbouwproducenten en besluiten van landbouwverenigingen en -organisaties hebben een bijzonder statuut onder het EU- mededingingsrecht. In de gemeenschappelijke marktordening wordt bepaald dat het mededingingsrecht op bepaalde soorten overeenkomsten en besluiten in de landbouw niet van toepassing is. De betreffende artikelen zijn echter niet duidelijk. Het Hof van Justitie heeft in een arrest van 14 november 2017 duidelijkheid geschapen. Besluiten van producentenorganisaties die noodzakelijk zijn ter uitvoering van hun bij wettelijke bepaling opgedragen taken zijn van het kartelverbod uitgesloten.

Hvf 14 november 2017, zaak C-671/15, Association des producteurs vendeurs d'endives (APVE), ECLI:EU:C: 2017:860

\section{Inleiding}

De verhouding tussen landbouwrecht en mededingingsrecht is speciaal. In principe zijn de mededingingsregels niet van toepassing op de landbouwsector. Het is aan de wetgever om te bepalen in hoeverre het mededingingsrecht geldt voor de landbouw. Dit is laatstelijk gebeurd in de gemeenschappelijke marktordening (art. 175 e.v. Verordening (EG) nr. 1234/2007, in 2013 vervangen door de art. 206 e.v. van Verordening (EU) nr. 1308/

* Mr. T.P.J.N. (Thomas) van Rijn is gewezen juridisch hoofdadviseur bij de Juridische Dienst van de Europese Commissie. De auteur dankt Maria Litjens, Johan van Haersolte en Marc Fierstra voor hun nuttige opmerkingen bij een eerdere versie van dit artikel.

1. Verordening (EG) nr. 1234/2007 van de Raad van 14 maart 2012 houdende gemeenschappelijke ordening van de landbouwmarkten en specifieke bepalingen voor een aantal landbouwproducten (Integrale GMO-verordening"), PbEG 2007, L 299/1.
$2013^{2}$ ). Deze artikelen muntten evenwel niet uit door helderheid. Met name is de vraag in hoeverre de in deze artikelen bepaalde vrijstelling of uitsluiting van de toepassing van het mededingingsrecht geldt voor overeenkomsten, feitelijke gedragingen of besluiten van producentenorganisaties en voor overeenkomsten tussen landbouworganisaties, bijvoorbeeld over de vaststelling van prijzen van landbouwproducten. ${ }^{3}$

Over deze vraag is nog geen jurisprudentie. Vandaar dat werd uitgezien naar het antwoord op prejudiciële vragen van de Cour de cassation (Frankrijk), die hierover moest oordelen in een geschil tussen de Franse mededingingsautoriteit (Autorité de la concurrence) en een groot aantal landbouworganisaties en producentenorganisaties met betrekking tot prijsafspraken in de sector productie en verhandeling van witlof.

Het hierna te bespreken arrest van het Hof van Justitie biedt veel duidelijkheid over de interpretatie van de hierboven genoemde artikelen. Het Hof van Justitie maakt onderscheid tussen overeenkomsten die landbouwers of landbouworganisaties met elkaar sluiten enerzijds en besluiten van producentenorganisaties anderzijds. Deze laatste genieten een gunstigere behandeling dan de eerste categorie wegens de bijzondere plaats die de gemeenschappelijke marktordening aan producentenorganisaties geeft.

Voordat op het arrest van het Hof van Justitie zal worden ingegaan, zullen kort de feiten in de zaak worden gereleveerd. Daarna zal een overzicht worden gegeven van relevante bepalingen van het Werkingsverdrag van de EU en van de gemeenschappelijke marktordening.

2. Verordening (EU) nr. 1308/2013 van het Europees Parlement en de Raad van 17 december 2013 tot vaststelling van een gemeenschappelijke ordening van de markten voor landbouwproducten en tot intrekking van de Verordeningen (EEG) nr. 922/72, (EEG) nr. 234/79, (EG) nr. 1037/2001 en (EG) nr. 1234/2007 van de Raad, PbEU 2013, L 347/671.

3. Zie over dit onderwerp H.C.E.P.J. Janssen en S. van der Heul, 'Aanbodbundeling en gezamenlijke verkoop van primaire landbouwproducten hoever reikt het kartelverbod?', NtEr 2015/5, p. 160-170. 
Het artikel zal worden afgesloten met een kort commentaar.

\section{Feiten}

De Franse mededingingsautoriteit (de Autorité de la concurrence) heeft op 6 maart 2012 een aantal organisaties die zich bezighouden met de productie en verkoop van witlof, waaronder producentenorganisaties, een boete opgelegd van bijna 4 miljoen euro omdat zij in de periode 1998 tot 2012 een naar Frans en Europees recht verboden mededingingsregeling hadden toegepast. ${ }^{4} \mathrm{Dit}$ kartel bevatte verschillende componenten waarmee de gezamenlijke vaststelling van een minimumverkoopprijs van de witlofteelt werd beoogd en telers en verschillende van hun beroepsorganisaties minimumverkoopprijzen konden handhaven. De witlofprijs werd met behulp van verschillende middelen onderling afgestemd: een wekelijkse minimumprijs werd verspreid, een klokprijs en een spilkoers vastgesteld, een uitwisselingsbeurs ingevoerd, en de ophoudprijsregeling werd oneigenlijk gebruikt. Verder vond overleg plaats over de hoeveelheid witlof die op de markt werd gebracht en werd strategische informatie uitgewisseld. Het argument van de organisaties dat het kartel noodzakelijk was voor de verwezenlijking van de doeleinden van het gemeenschappelijk landbouwbeleid in de zin van de artikel 2 lid 1 van Verordening (EG) nr. 1184/2006 en artikel 176 van Verordening (EG) nr. 1234/2007, werd door de Autorité de la concurrence afgewezen.

In beroep heeft de Cour d'appel het besluit van de Autorité de la concurrence herzien en geoordeeld dat niet bewezen was dat het Franse recht en artikel 101 VWEU waren geschonden. ${ }^{5} \mathrm{Nu}$ de interpretatie van de wetgeving inzake de gemeenschappelijke landbouwmarkten onduidelijk was met betrekking tot de omvang en grenzen van de prijsreguleringstaken die de betrokken organisaties in het kader van het afwijkende mededingingsregime waren opgedragen, was niet bewezen dat de verspreiding van instructies voor minimumprijzen in alle omstandigheden noodzakelijkerwijs en definitief verboden was, zodat niet onbetwistbaar was vastgesteld dat de betrokken organisaties de grenzen hadden overschreden van de taken die hun op het gebied van de prijsregulering waren opgedragen.

De president van de Autorité de la concurrence heeft cassatieberoep ingesteld, waarbij hij in essentie stelde dat - buiten het geval waarin de uitdrukkelijke uitzonderingen op de toepassing van artikel 101 lid 1 VWEU vermeld in artikel 2 lid 1 van Verordening (EG) nr. 1184/2006 en artikel 176 van Verordening (EG) nr. 1234/2007 van toepassing zijn - de uitoefening van de taken die aan producentenorganisaties (hierna: PO's) en unies van producentenorganisaties (hierna: UPO's) waren opgedragen alleen met eerbiediging van de mededingingsregels kon geschieden.

In het kader van de procedure bij de Cour de cassation heeft de Europese Commissie op basis van artikel 15 lid 3 van Verordening (EG) nr. 1/2003 ${ }^{6}$ opmerkingen ingediend. $\mathrm{Zij}$ heeft uiteengezet dat bij de toepassing van de mededingingsregels van de Unie op de landbouwsector niet alleen de algemene uitzonderingen die zijn vastgesteld op de grondslag van artikel 2 van Verordening 26 en Verordening (EG) nr. 1184/2006 alsook van artikel 176 van Verordening (EG) nr. 1234/2007 gelden. Overeenkomstig artikel 175 van deze verordening zijn ook bepaalde in Verordening (EG) nr. 1234/2007 opgenomen specifieke uitzonderingen van toepassing, waarbij organisaties die werkzaam zijn op het gebied van de productie van en de handel in groenten en fruit worden belast met bepaalde bijzondere taken die normaal gesproken onder de verboden van de mededingingsregels zouden kunnen vallen. De Commissie meent evenwel dat de belangrijkste gedragingen in het hoofdgeding, te weten de minimumprijsregelingen die zijn overeengekomen binnen de belangrijkste UPO's, buiten de door de gemeenschappelijke ordening van de betreffende markt gegeven specifieke opdrachten vallen en niet kunnen worden geacht onder deze specifieke uitzonderingen te vallen.

De Cour de cassation was van oordeel dat het Hof van Justitie zich nog niet had uitgesproken over de verhouding van de algemene afwijking van artikel 175 van Verordening (EG) nr. 1234/20107 met de specifieke afwijkingen van met name artikel 176 van deze verordening. Het heeft derhalve twee prejudiciële vragen gesteld. ${ }^{7}$ De eerste betreft de vraag of overeenkomsten, besluiten of gedragingen van producentenorganisaties, unies van producentenorganisaties en beroepsorganisaties die in het licht van artikel 101 VWEU als mededingingsverstorend kunnen worden aangemerkt, buiten het verbod van dat artikel vallen, alleen omdat zij in verband kunnen worden gebracht met de aan die organisaties in het kader van de gemeenschappelijke marktordening gegeven opdrachten, hoewel zij onder geen enkele algemene afwijking in de zin van met name artikel 176 van Verordening (EG) nr. 1234/2007 vallen. Vervolgens vroeg de Cour de cassation of gedragingen als de collectieve vaststelling van een minimumprijs, overleg over de op de markt gebrachte hoeveelheden of uitwisseling van strategische informatie, door die organisaties of hun unies, buiten het mededingingsverbod vallen, voor zover zij streven naar de verwezenlijking van de in artikel 122 van Verordening (EG) nr. 1234/2007 geformuleerde doelstellingen van regulering van de producentenprijzen en aanpassing van de productie aan de vraag. 


\section{Toepasselijke wettelijke bepalingen}

Omdat het kartel een lange periode heeft beslagen, zijn verschillende wettelijke stelsels in de tijd van toepassing, hetgeen tot uitdrukking komt in het arrest van het Hof van Justitie. Ik zal mij hier concentreren op de regels die van 2007 tot en met 2012 golden. De gemeenschappelijke marktordening is in 2013 opnieuw gewijzigd; voor de duidelijkheid zal ik op de toepasselijke plaatsen in de voetnoten naar deze bepalingen verwijzen.

Artikel $42 \mathrm{VWEU}^{8}$ bepaalt dat de mededingingsregels slechts van toepassing zijn op de landbouw voor zover dit door het Europees Parlement en de Raad is bepaald. Dit betekent dat volgens het Werkingsverdrag de landbouwbepalingen in principe boven de mededingingsregels gaan.

De Raad heeft in 1962 bij Verordening 26 al bepaald dat de artikelen 85 en 86 EEG-Verdrag van toepassing zijn op de landbouw, maar heeft een aantal uitzonderingen geformuleerd. Deze verordening is in 2006 gecodificeerd en vervangen door Verordening (EG) nr. 1184/2006. Deze uitzonderingen betreffen met name overeenkomsten, besluiten en gedragingen die vereist zijn voor de verwezenlijking van de in artikel 39 EEG-Verdrag ${ }^{9}$ geformuleerde doelstellingen van het landbouwbeleid of die gesloten zijn tussen ondernemingen of ondernemersverenigingen in de landbouw uit dezelfde lidstaat mits zij geen verplichting inhouden een bepaalde prijs toe te passen. Deze voorwaarde betekende dat de uitzondering in de onderhavige zaak niet van toepassing was.

De bepaling dat de artikelen 81 en 82 EG-Verdrag ${ }^{10}$ van toepassing zijn op de landbouw onder voorbehoud van de uitzonderingen die al in Verordening (EG) nr. 1184/2006 stonden, is in 2007 in de gemeenschappelijke marktordening, Verordening (EG) nr. 1234/2007, opgenomen. ${ }^{11}$

Artikel 175 van Verordening (EG) nr. 1234/2007 is als volgt geformuleerd:

'Tenzij in deze verordening anders is bepaald, gelden de artikelen 81, lid 1, en 82 van het Verdrag, evenals de daarvoor vastgestelde uitvoeringsbepalingen, voor alle in artikel 81, lid 1, en artikel 82 van het Verdrag bedoelde overeenkomsten, besluiten en gedragingen die betrekking hebben op de productie van of de handel in de in deze verordening vermelde producten, onder voorbehoud van de artikelen 176 tot en met 177 van deze verordening. ${ }^{12}$

8. Deze bepaling kwam onder hetzelfde nummer al voor in het EEG-Verdrag.

9. Nu art. 39 VWEU

10. Nu art. 101 en 102 VWEU.

11. Art. 175 en 176 Verordening (EG) nr. 1234/2007. Deze bepalingen vervangen in feite de art. 1 bis en 2 van Verordening (EG) nr. 1184/2006.

12. Vervangen door art. 206 van Verordening (EU) nr. 1308/2013.
In artikel $176^{13}$ staan letterlijk de uitzonderingen van artikel 2 lid 1 van Verordening 26 en Verordening (EG) nr. 1184/2006. Artikel 176bis ${ }^{14}$ bevat een uitzondering op de toepasselijkheid van de mededingingsregels voor bepaalde overeenkomsten, besluiten en onderling afgestemde feitelijke gedragingen van brancheorganisaties in de sector groenten en fruit en artikel $177^{15}$ een vergelijkbare uitzondering voor de tabakssector.

De aanvangswoorden van artikel 175, 'Tenzij in deze verordening anders is bepaald', zijn vaag. In de literatuur is de vraag opgeworpen of zij bijvoorbeeld verwijzen naar de bevoegdheden van PO's, zoals bepaald in artikel 122 van Verordening (EG) nr. 1234/2007 en voor gedragingen van PO's een algemene wettelijke uitzondering op het kartelverbod vormen of dat deze aanvangswoorden doelen op bepalingen die uitdrukkelijk de toepassing van de mededingingsregels uitsluiten. ${ }^{16}$ Deze vraag heeft zijn neerslag gevonden in de prejudiciële vraag van de Cour de cassation.

In Verordening (EU) nr. 1234/2007 zijn bepalingen opgenomen met betrekking tot PO's en UPO's die van toepassing waren op bepaalde producten, waaronder vooral groenten en fruit. Dergelijke bepalingen kwamen voordien al voor, onder andere in de marktordening voor groenten en fruit. Een PO kan door de lidstaat waar zij gevestigd is, officieel worden erkend indien bepaalde doelstellingen worden nagestreefd. Tot deze doelstellingen behoren de planning van de productie en de aanpassing van de productie aan de vraag, met name wat de omvang en kwaliteit betreft, de concentratie van het aanbod en het op de markt brengen van de producten van de leden en het optimaliseren van de productiekosten en stabiliseren van de producentenprijzen (art. 122 e.v. $\left.{ }^{17}\right)$. De erkenning is in de groente- en fruitsector van belang voor subsidieverlening (art. 103 bis e.v. ${ }^{18}$ ) en voor de mogelijkheid om door de PO uitgevaardigde voorschriften verbindend te laten verklaren voor nietleden van de PO (art.125septies $\left.{ }^{19}\right)$. Gezien deze doelstellingen kunnen besluiten van een PO een mededingingsbeperkende strekking of gevolgen hebben, bijvoorbeeld indien zij het aanbod op de markt beperken of ver-

13. Vervangen door art. 209 van Verordening (EU) nr. 1308/2013.

14. Vervangen door art. 210 van Verordening (EU) nr. 1308/2013.

15. Vervangen door art. 210 van Verordening (EU) nr. 1308/2013.

16. Zie Von Rintelen, 'Producer organisations, interbranch organisations, operator organisations', in: R. Mögele and F. Erlbacher (red.), Sing/e Common Market Organisation, Article-by-Article Commentary of the Legal Framework for Agricultural Markets in the European Union, München: Beck 2011, p. 527 e.v.; Van Rijn 'Artikel 42 AEUV', in: Von der Groeben/Schwarze, Hatje (Hrsg), Europäisches Unionsrecht, BadenBaden: Beck, 7e editie 2015 en Von Rintelen, 'AEUV art. 42,' in: E. Grabitz, M. Hilf en M. Nettesheim, Das Recht der Europäischen Union: EUV/AEUV, München: Beck 2016, randnrs. 42-49. Vgl. ook de nu in deze niet meer relevant zijnde Richtsnoeren van de Commissie voor de toepassing van de in de art. 169, 170 en 171 van de GMO-verordening vastgestelde specifieke regels voor de sectoren olijfolie, rundvlees en akkerbouwgewassen, PbEU 2015, C 431/1 (deze artikelen zijn geschrapt bij Verordening (EU) 2017/2393)

17. Vervangen door art. 152 van Verordening (EU) nr. 1308/2013. De bepaling is uitgebreid tot alle landbouwsectoren.

18. Vervangen door art. 32 e.v. van Verordening (EU) nr. 1308/2013.

19. Vervangen door art. 164 van Verordening (EU) nr. 1308/2013. De bepaling is uitgebreid tot alle landbouwsectoren. 
koopprijzen vaststellen. De vraag is of de aanvangswoorden van artikel 175 aan deze besluiten refereerden.

\section{Het arrest van het Hof van Justitie}

Het arrest van het Hof van Justitie valt uiteen in drie delen:

a. de verdragsrechtelijke verhouding tussen het landbouwbeleid en het mededingingsrecht;

b. de positie en taken van de PO's en UPO's binnen de gemeenschappelijke marktordening;

c. de mededingingsrechtelijke beperkingen van de gedragingen van PO's en UPO's.

Ad a. de verdragsrechtelijke verhouding tussen

het landbouwbeleid en het mededingingsrecht

Artikel 42 VWEU bepaalt dat de mededingingsbepalingen slechts van toepassing zijn op de landbouw voor zover de Uniewetgever dit bepaalt. Het Hof van Justitie trekt hier de conclusie uit dat het gemeenschappelijk landbouwbeleid voorrang heeft op de doelstellingen van het Verdrag op het gebied van de mededinging. ${ }^{20}$ Het optreden van de Uniewetgever heeft dan tot doel om te bepalen in hoeverre gedragingen die in andere sectoren van de economie dan het gemeenschappelijk landbouwbeleid onder het mededingingsverbod zouden vallen, van de werkingssfeer van de artikelen 101 en 102 VWEU uitgesloten moeten worden. ${ }^{21}$ Artikel 175 van Verordening (EG) nr. 1234/2007 regelt de onderlinge samenhang tussen het gemeenschappelijk landbouwbeleid en de mededingingsregels. ${ }^{22}$

Ad b. de positie en taken van de PO's en UPO's binnen de gemeenschappelijke marktordening Het Hof van Justitie gaat vervolgens over naar de artikelen 122 en 125quater van Verordening (EG) nr. 1234/2007 waarin wordt bepaald dat een PO of UPO tot taak heeft te verzekeren dat de productie wordt gepland en aan de vraag wordt aangepast, met name wat omvang en kwaliteit betreft, het aanbod en het op de markt brengen van de producten van haar leden te concentreren of de productiekosten te optimaliseren en de producentenprijzen te stabiliseren. ${ }^{23} \mathrm{Om}$ deze doelstellingen te kunnen vervullen zal de PO of UPO gebruik moeten maken van andere middelen dan de middelen waarmee normale marktwerking wordt geregeld en, in het bijzonder, van bepaalde vormen van afstemming en overleg tussen landbouwproducenten. ${ }^{24}$ Voor zover deze gedragingen noodzakelijk zijn voor het bereiken van de doelstellingen dienen zij dientengevolge buiten het verbod van artikel 101 lid 1 VWEU te vallen. ${ }^{25}$ Hieruit volgt dat de gevallen waarin artikel 101 lid 1 VWEU niet van toepassing is, niet beperkt zijn tot die welke bedoeld worden in de artikelen 176 en 176bis van Verordening (EG) nr. 1234/2007, maar ook in geval van gedragingen die noodzakelijk zijn voor een PO of UPO om haar doelstellingen te bereiken. ${ }^{26}$

Ad c. de mededingingsrechtelijke beperkingen van de gedragingen van PO's en UPO's

De draagwijdte van de uitsluiting van de toepassing van de mededingingsregels moet volgens het Hof van Justitie strikt worden uitgelegd. ${ }^{27}$ De reden hiervoor is dat de gemeenschappelijke marktordening niet van de mededinging is uitgesloten. Zoals in het arrest Milk Marque en National Farmers Union ${ }^{28}$ immers is gezegd vormt de handhaving van een echte mededinging juist een van de doelstellingen van het gemeenschappelijk landbouwbeleid. ${ }^{29} \mathrm{Om}$ uitgesloten te zijn van de toepassing van het kartelverbod mogen de gedragingen van PO's en UPO's niet verder gaan dan strikt noodzakelijk is voor het bereiken van de hun in de gemeenschappelijke marktordening opgedragen doelstellingen. ${ }^{30}$

Dit betekent dat deze gedragingen alleen ten uitvoer kunnen worden gelegd 'door een entiteit die daar krachtens de regelgeving inzake de gemeenschappelijke ordening van deze markt daadwerkelijk toe bevoegd was en die derhalve door een lidstaat was erkend'. ${ }^{31}$ Dit sluit beroepsorganisaties, andere dan erkende producentenof brancheorganisaties, uit. ${ }^{32}$

De gedragingen moeten beperkt blijven 'tot de interne gedragingen binnen de PO of UPO', omdat 'de taken ... slechts betrekking hebben op de productie en de afzet van de producten van de afzonderlijke leden van de betreffende PO of UPO' en dus 'alleen een rechtvaardiging bieden voor bepaalde vormen van afstemming en overleg tussen producenten die lid zijn van een en dezelfde door een lidstaat erkende PO of UPO'. Overeenkomsten tussen PO's en tussen UPO's gaan verder dan voor de uitvoering van de taken nodig is ${ }^{33}$ en vallen dus niet onder de niet-toepasselijkheid van de mededingingsregels.

Vervolgens gaat het Hof van Justitie over tot het bespreken van de concrete mededingingsbeperkingen die in de onderhavige zaak aan de orde waren. Allereerst buigt het Hof van Justitie zich over het uitwisselen van strategische informatie. Het acht deze uitwisseling evenredig 'indien deze uitwisseling daadwerkelijk bijdraagt tot de verwezenlijking van de aan deze PO of UPO opgedragen
20. HvJ 14 november 2017, zaak C-671/15, Association des producteurs vendeurs d'endives, ECLI:EU:C:2017:860, punt 37. Het Hof van Justitie verwijst naar HvJ 5 oktober 1994, zaak C-280/93, Duitsland/Raad, ECLI:EU:C:1994:367.

21. Association des producteurs vendeurs d'endives, punt 38. Hetzelfde geldt voor de art. 107 e.v. VWEU inzake steunmaatregelen, maar deze stonden in de onderhavige zaak niet ter discussie.

22. Association des producteurs vendeurs d'endives, punt 39

23. Association des producteurs vendeurs d'endives, punt 42

24. Association des producteurs vendeurs d'endives, punt 43 
doelstelling of doelstellingen en beperkt blijft tot enkel de informatie die strikt noodzakelijk is voor dit doel' ${ }^{34}$ De onderlinge afstemming door de leden van een PO of UPO over de op de markt te brengen hoeveelheden kan gerechtvaardigd worden door de doelstelling om de producentenprijzen te stabiliseren. ${ }^{35}$

'(D)e doelstelling het aanbod te concentreren teneinde de positie van de producenten tegenover een steeds sterkere concentratie van de vraag te verbeteren, (kan) eveneens een rechtvaardiging bieden voor een bepaalde onderlinge afstemming van de tariefpolitiek van individuele landbouwproducenten binnen een PO of UPO. ${ }^{36}$ Dit is vooral het geval binnen de groente- en fruitsector waar artikel 125bis lid 1 sub c jo. 125quater van Verordening (EG) nr. 1234/2007 de producenten, behalve in bijzondere gevallen, de verplichting oplegt om hun totale productie via de PO of UPO te verkopen.

De collectieve vaststelling van minimumverkoopprijzen binnen een PO of UPO kan daarentegen niet als evenredig aan het bereiken van de doelstellingen van prijsstabilisatie of concentratie van het aanbod beschouwd worden, wanneer producenten, die, zoals in de groente- en fruitsector (in de gevallen bedoeld in art. 125bis lid 2 van Verordening (EG) nr. 1234/2007), hun eigen productie zelf afzetten, geen prijs onder deze minimumprijs mogen hanteren. ${ }^{37}$

\section{Opmerkingen}

\section{Mededingingsvrije ruimte voor bepaalde}

landbouwkartels

Dit arrest, gewezen door de Grote Kamer, is belangrijk voor de verhouding tussen het gemeenschappelijk landbouwbeleid en het mededingingsrecht. Het Hof van Justitie aanvaardt in het algemeen ${ }^{38}$ dat mededingingsbeperkende gedragingen in de landbouw die noodzakelijk zijn om de taken uit te voeren die de wetgever aan organisaties ter uitvoering van het gemeenschappelijk landbouwbeleid heeft opgedragen, van de toepassing van artikel 101 lid $1 \mathrm{VWEU}$ zijn uitgesloten. Daarmee is een mededingingsvrije ruimte voor deze organisaties gecreëerd.

Deze mededingingsvrije ruimte is inherent aan de opgedragen taken. De wetgever hoeft de niet-toepasselijkheid van het kartelverbod niet uitdrukkelijk te bepalen. ${ }^{39}$ Het Hof van Justitie heeft er niet voor gekozen om artikel 175 van Verordening (EG) nr. 1234/2007 en met name de aanvangswoorden 'Tenzij in deze verordening anders is bepaald' te interpreteren. Het Hof van Justitie gaat uit van de inherente logica van de gemeen-

34. Association des producteurs vendeurs d'endives, punt 63

35. Association des producteurs vendeurs d'endives, punt 64

36. Association des producteurs vendeurs d'endives, punt 65

37. Association des producteurs vendeurs d'endives, punt 66 .

38. Dus ook voor andere sectoren dan de groente- en fruitsector, waar het in de onderhavige zaak over gaat.

39. Dit is wel gedaan in art. 152 lid 1 bis (na de wijziging door Verordening (EU) 2017/2393) schappelijke marktordening. Als de door de wetgever ter uitvoering van het gemeenschappelijk landbouwbeleid opgedragen taken niet zouden kunnen worden verricht omdat in strijd met het kartelverbod zou moeten worden gehandeld, zou de wetgeving immers innerlijk tegenstrijdig zijn. In dat geval moet de voorrangsregel van artikel 42 VWEU worden toegepast en moeten de mededingingsregels buiten toepassing blijven.

Advocaat-generaal Wahl geeft een iets andere analyse. Volgens hem kan er geen sprake zijn van een mededingingsverstorende gedraging in de zin van artikel 101 lid 1 VWEU, zodra deze 'plaatsvindt in een niet-concurrerende omgeving, die vooral het gevolg is van het feit dat deze gedraging direct in verband kan worden gebracht met de vervulling van de opdrachten die krachtens de toepasselijke regelgeving aan de actoren binnen de GMO's zijn toegewezen'. ${ }^{40}$ Langs deze weg komt hij tot de conclusie dat er dan sprake is van een uitsluiting van de mededingingsregels en niet van een afwijking, zoals in artikel 209 van Verordening (EU) nr. 1308/2013. ${ }^{41}$ 'Uitsluiting' betekent dat de mededingingsregels in het algemeen niet van toepassing zijn, terwijl bij 'afwijking' die regels wel toepasselijk zijn, maar er gronden zijn om ze in een bepaald geval niet toe te passen.

Dit betekent dat er op het nu in artikel 206 van de gemeenschappelijke marktordening (Verordening (EU) nr. 1308/2013) neergelegde beginsel dat de artikelen 101 en 102 VWEU van toepassing zijn op overeenkomsten, feitelijke gedragingen en besluiten met betrekking tot de productie van en de handel in landbouwproducten, drie categorieën uitzonderingen zijn. De eerste categorie wordt gevormd door overeenkomsten, besluiten en feitelijke gedragingen die vereist zijn voor de verwezenlijking van de in artikel 39 VWEU omschreven doelstellingen en die welke gesloten zijn tussen landbouwers, (unies van) verenigingen van landbouwers en (unies van) producentenorganisaties in één en dezelfde lidstaat die de doelstellingen van artikel 39 VWEU niet in gevaar brengen (art. 209 van Verordening (EU) nr. 1308/2013). Onder de tweede categorie vallen gedragingen die in Verordening (EU) nr.1308/2013 of haar uitvoeringsverordeningen uitdrukkelijk van het toepassingsgebied van artikel 101 lid 1 VWEU zijn uitgesloten. ${ }^{42}$ Een derde categorie heeft het Hof van Justitie er in dit arrest aan toegevoegd, namelijk gedragingen van organisaties waaraan in de gemeenschappelijke marktordening taken zijn opgedragen die noodzakelijk zijn om de doelstellingen van de producentenorganisatie te

40. Conclusie A-G inzake Association des producteurs vendeurs d'endives, ECLI:EU:C:2017:281, nrs. 49-50 en 71

41. De terminologie heeft volgens A-G Wahl 'aanzienlijke gevolgen voor zowel de methode van het onderzoek van de door de actoren binnen de GMO's genomen maatregelen als de bewijslast ter zake van de mogelijk mededingingsverstorende aard van deze maatregelen', zie nrs. 52-54 van de Conclusie.

42. Alleen sinds 1 januari 2018 art. 152 lid 1 bis (toegevoegd door wijzigingsverordening (EU) 2393/2017) van Verordening (EU) $\mathrm{nr}$. $1308 / 2013$ en uitvoeringsverordening op basis van art. 222 van Verordening (EU) nr. 1308/2013 (bijv. Verordening (EU) 2016/559, PbEU 2016, L 96/20) 
bereiken, ook als de uitsluiting van het kartelverbod niet uitdrukkelijk in een bepaling is vastgelegd.

De vraag kan worden gesteld of het nodig is dat de wetgeving specifieke taken aan producentenorganisaties opdraagt of dat handelen in het kader van de algemene doelstellingen voldoende is. In haar opmerkingen aan de Cour de cassation uit hoofde van artikel 15 lid 3 van Verordening (EG) nr. 1/2003 gaat de Commissie van het eerste uit, verwijzend naar taken, zoals het uit de markt nemen van producten (art. 103quater lid 2 sub a van Verordening (EG) nr. 1234/2007). ${ }^{43}$ Gedragingen die slechts in overeenstemming zijn met de algemene doelstellingen van een producentenorganisatie (art. 122, eerste alinea, van Verordening (EG) nr. 1234/2007) zouden volgens haar niet volstaan om de niet-toepasselijkheid van artikel 101 lid 1 VWEU aan te nemen. ${ }^{44}$ Het Hof van Justitie gaat mijns inziens uit van een ruimere visie nu het in rechtsoverwegingen 42-44 van het arrest een verband legt tussen de doelstellingen van producentenorganisaties en unies van producentenorganisaties in het algemeen en de gedragingen die noodzakelijk zijn om deze doelstellingen te bereiken.

Alleen besluiten van erkende organisaties Het arrest is geheel afgestemd op producentenorganisaties (PO's) en unies van producentenorganisaties (UPO's). Dit komt doordat verschillende PO's en UPO's tot de partijen in de hoofdzaak behoorden en dat de gemeenschappelijke marktordening aan deze organisaties bepaalde bevoegdheden heeft gegeven. De mededingingsvrije ruimte die het arrest opent, zou eventueel ook voor andere erkende organisaties kunnen gelden. Aan brancheorganisaties worden in artikel 157 van Verordening (EU) nr. 1308/2013 bijvoorbeeld ook bepaalde bevoegdheden gegeven, maar deze lijken minder mededingingsgevoelige materies te betreffen. Overigens wordt voor overeenkomsten en onderling afgestemde feitelijke gedragingen van erkende brancheorganisaties al een aparte uitzondering voorzien in artikel 210 van Verordening (EU) nr.1308/2013. Deze bijzondere regeling, die een interventie van de Commissie inhoudt, betekent mijns inziens evenwel dat brancheorganisaties niet automatisch kunnen genieten van een mededingingsvrije ruimte die uit artikel 157 zou voortvloeien.

De mededingingsvrije ruimte geldt alleen voor organisaties die erkend zijn. De erkenning is voor PO's en UPO's geregeld in de artikelen 154 en 156 van Verordening (EU) nr.1308/2013 en voor brancheorganisaties in artikel 158 van deze verordening. ${ }^{45} \mathrm{Zij}$ brengt tot uiting dat de erkende organisatie een instrument is van de gemeenschappelijke landbouwpolitiek. De activiteiten van in het bijzonder PO's en UPO's, met name de plan-

43. Ook A-G Wahl lijkt hiervan uit te gaan nu hij spreekt van 'specifieke maatregelen', zie Conclusie, nr. 94. Deze taak is niet meer opgenomen in Verordening (EU) nr. 1308/2013, zie art. 33.

44. Observations de la Commission européenne en application de l'article 15, paragraphe 3 , du règlement (CE) $\Pi^{\circ} 1 / 2003$ du 27.2.2015 <http://ec.europa.eu/competition/court/antitrust_amicus_curiae.html>, nrs. 139, 142-143.

45. Meer over de erkenning bij Janssen en Van der Heul, in NtEr 2015, p. 162 ning van de productie, de concentratie van het aanbod op de markt en het stabiliseren van de prijzen dragen immers bij tot de verwezenlijking van een van de doeleinden van artikel 39 VWEU, namelijk het verzekeren van een redelijke levensstandaard voor de landbouwbevolking.

\section{Alleen voor interne afspraken binnen de organisatie}

Wat de onder de mededingingsvrije ruimte vallende gedragingen betreft, formuleert het Hof van Justitie duidelijke grenzen. Alleen interne overeenkomsten en gedragingen binnen een PO en UPO, die de wettelijk opgedragen taken uitvoeren, zijn van het kartelverbod uitgezonderd. Dat is logisch, omdat de gemeenschappelijke marktordening de taken van de PO en UPO beperkt tot bepaalde vormen van coördinatie tussen de leden van de organisatie. Onder interne gedragingen valt ook de vaststelling door de PO of UPO van de verkoopprijs van de op de markt gebrachte producten, welke ook de juridische kwalificatie van de gedraging is. ${ }^{46}$ Coördinatie van gedragingen met organisaties buiten de PO of UPO of tussen PO's en UPO's wordt duidelijk niet door de taken van een PO of UPO gedekt. ${ }^{47}$

Advocaat-generaal Wahl motiveert de beperking tot interne afspraken binnen een PO of UPO met het argument dat deze praktijken gelijkgesteld kunnen worden met afspraken 'binnen een vennootschap of een groep die zich, op de betrokken markt en rekening houdend met de bijzonderheden van de landbouwmarkt, presenteert als één en dezelfde economische entiteit. Dergelijke "interne" praktijken zijn onttrokken aan het mededingingsrecht.' De leden/landbouwers zouden geen controle meer hebben over de verkoop van hun producten en de prijs. ${ }^{48} \mathrm{Ik}$ denk echter dat dit niet in het algemeen zo te stellen is. Dit zal afhangen van de statuten van de PO of UPO. ${ }^{49}$ Daarom lijkt mij de lijn van het Hof van Justitie beter.

Dat het Hof van Justitie de onderlinge uitwisseling van strategische informatie die inherent is aan de vervulling van de taken en de afstemming van hoeveelheden die op de markt worden gebracht onder de mededingingsvrije ruimte brengt, is begrijpelijk, omdat deze gedragingen rechtstreeks voortvloeien uit de aan de PO of UPO in artikel 152 of artikel 154 van Verordening (EU) nr. 1308/2013 toegekende bevoegdheden.

Het arrest is evenwel niet zo duidelijk als het gaat om de onderlinge afstemming van de tariefpolitiek, bijvoorbeeld een te berekenen minimumprijs. Deze is geoor-

46. Wanneer de leden de eigendom van de aan de PO of UPO geleverde producten overdragen, is het de vraag of er bij de bepaling van de verkoopprijs door de PO of UPO nog wel van een besluit van de PO of UPO of onderling afgestemde gedraging kan worden gesproken.

47. Vgl. Conclusie A-G Wahl, nrs. 94-96. De vraag is of een dergelijke coördinatie wel mogelijk zou zijn onder art. 222 van Verordening (EU) nr. 1308/2013.

48. Conclusie A-G Wahl, nrs. 101-103. In deze zin ook Janssen en Van der Heul in NtEr 2015, p. 163.

49. Vgl. Richtsnoeren van de Commissie voor de toepassing van de in de art. 169, 170 en 171 van de GMO-verordening vastgestelde specifieke regels voor de sectoren olijfolie, rundvlees en akkerbouwgewassen, PbEU 2015, C 431/, nr. 18. 
loofd 'indien de leden van de betrokken PO of UPO aan deze organisatie de taak hebben toevertrouwd om hun hele productie te verkopen', zoals in de groente- en fruitsector. ${ }^{50}$ Wanneer maar een deel van de productie aan de PO of UPO wordt verkocht, is de vaststelling van een minimumverkoopprijs niet geoorloofd voor het deel van de producten dat de leden zelf verkopen. ${ }^{51}$

Het is mij niet duidelijk wat de ratio van deze beperking is. In beide gevallen draagt de minimumprijs bij aan de stabilisatie van de prijs op de markt, hetgeen een van de taken van de PO en UPO is. Dit zou ervoor pleiten dat ieder afstemmen door de PO of UPO van de tariefpolitiek van haar leden onder de mededingingsvrije ruimte valt. Overigens komt de leveringsplicht van de leden aan de PO alleen voor in de groente- en fruitsector (nu in art. 160 van Verordening (EU) nr. 1308/2013) en zijn de in punt 66 van het arrest genoemde uitzonderingen (zie art. 125bis lid 2 van Verordening (EG) nr. 1234/2007) niet meer in de huidige gemeenschappelijke marktordening opgenomen.

Hier kan tegenin gebracht worden dat krachtens artikel 209 van Verordening (EU) nr. 1308/2013 gedragingen die de verplichting inhouden identieke prijzen toe te passen buiten de uitzondering op het kartelverbod vallen. Ook erkende brancheorganisaties mogen geen overeenkomsten sluiten die de vaststelling van prijzen omvatten (art. 210 lid 4 sub d van Verordening (EU) nr. 1308/2013). Collectieve vaststelling van de prijzen wordt in deze bepalingen als een ernstige mededingingsbeperking beschouwd die de voorrang moet krijgen boven de landbouwpolitieke voordelen van de gedraging of overeenkomst.

Dat het Hof van Justitie oordeelt dat de collectieve vaststelling van de verkoopprijzen bij verkoop door de $\mathrm{PO}$ of UPO van de gehele productie van de leden desalniettemin buiten het toepassingsgebied van het kartelverbod valt, kan verklaard worden door het feit dat bij de verkoop van de gehele productie door de PO of UPO de verkoopprijs noodzakelijkerwijze collectief, dat wil zeggen bij besluit van de PO of UPO, vastgesteld moet worden. ${ }^{52}$ Van dezelfde logica gaan de artikelen 149 lid 2 sub b en 152 lid 1bis sub $\mathrm{c}^{53}$ van Verordening (EU) nr. 1308/2013 betreffende contractuele onderhandelingen uit. Als een PO onderhandelt over de verkoop van producten, maakt de prijs daarvan een noodzakelijk onderdeel uit en geldt deze voor de productie van alle leden.

Het oordeel van het Hof van Justitie dat de vaststelling door leden van een PO of UPO van een minimumprijs voor producten die zij buiten de PO of UPO verkopen niet van het toepassingsgebied van artikel 101 lid 1

50. Association des producteurs vendeurs d'endives, punt 65 .

51. A-G Wahl meent dat de vaststelling van een minimumprijs in geen enkel geval van de toepassing van art. 101 lid 1 VWEU kan zijn uitgesloten, omdat de verkoop door de PO of UPO noodzakelijkerwijze neerkomt op de vaststelling van een eenheidsprijs, zie Conclusie nrs. 116-117.

52. Vgl. Gerecht 16 september 2013, zaak T-343/11, Nederland/Commissie, ECLI:EU:T:2013:468, punt 123

53. Zoals ingevoegd bij Verordening (EU) 2017/2393.
VWEU is uitgesloten, lijkt in overeenstemming te zijn met de artikelen 209 en 210 van de gemeenschappelijke marktordening. Het Hof van Justitie verwijst hier overigens niet naar. Het motiveert zijn stellingname door te wijzen op het feit dat de door de groepering in PO's en UPO's toch al beperkte concurrentie op de landbouwmarkt door een dergelijke gedraging nog verder verzwakt zou worden.

Advocaat-generaal Wahl geeft een andere motivering. Hij wijst op de effectiviteit van de rol die PO's en UPO's spelen bij de concentratie van het aanbod en daardoor op de stabilisatie van de prijzen. Alleen indien de prijsafspraken de volledige productie van de leden van de organisatie betreffen, kan de organisatie doeltreffend invloed uitoefenen op de stabilisatie van de prijzen, zo begrijp ik zijn standpunt. Zelfs de verkoop van een aanzienlijk deel van de productie is niet voldoende om een mededingingsvrije ruimte voor de afspraken te aanvaarden. ${ }^{54} \mathrm{Ik}$ vraag me echter af of deze stellingname niet te zeer is beinvloed door de groente- en fruitsector, waar het in de hoofdzaak om ging.

Artikel 152 lid 1bis van Verordening (EU) nr. 1308/ 2013, zoals ingevoegd bij Verordening (EU) 2017/2393, gaat immers uitdrukkelijk ervan uit dat maatregelen die de PO's nemen ook een gedeelte van de productie van de leden kan omvatten. ${ }^{55}$ In weerwil van het onderhavige arrest zouden deze maatregelen mijns inziens wel onder de niet-toepasselijkheid van de mededingingsregels kunnen vallen. Wel betreft het dan bijvoorbeeld prijsafspraken $^{56}$ die door de PO worden besloten, niet door individuele leden van de organisatie onderling voor het gedeelte van hun productie dat zij zelf verkopen. In dit laatste geval is artikel 101 lid 1 VWEU van toepassing. 57

Samenvattend kan gesteld worden dat interne gedragingen van erkende PO's en UPO's betreffende de planning van de productie, de concentratie van het aanbod en de stabilisatie van de prijzen van de toepassing van artikel 101 lid 1 VWEU zijn uitgesloten indien deze noodzakelijk zijn voor de vervulling van door de gemeenschappelijke marktorganisatie aan deze organisaties opgedragen taken en niet verder gaan dan voor deze vervulling nodig is. Dit geldt met name voor de vaststelling van de prijzen van de op de markt gebrachte producten. Overeenkomsten tussen PO's en UPO's, van deze organisaties met andere organisaties en tussen individuele leden van een organisatie genieten niet van deze mededingingsvrije ruimte, maar kunnen eventueel van de toepassing van artikel 101 lid 1 VWEU worden uitgezonderd op grond van artikel 209 van Verordening (EU) nr. 1308/2013 of artikel 101 lid 3 VWEU.

54. Conclusie, nrs. 99-100.

55. Vgl. Gerecht 30 september 2019, zaak T-432/07, Frankrijk/Commissie, ECLI:EU:T:2009:373, punt 54

56. De tekst van art. 152 lid 1 bis 2 e alinea sub c roept twijfel op of prijsafspraken ook een gedeelte van de productie van de afzonderlijke leden kan betreffen (die dan de rest van de productie individueel verkopen). De tekst spreekt immers over 'de gecombineerde productie van alle dan wel een deel van de leden'.

57. Vgl. Conclusie A-G Wahl, nr. 128. 


\section{Situatie in Nederland}

De Nederlandse instanties hebben zich niet expliciet uitgesproken over het bestaan van een mededingingsvrije ruimte voor gedragingen van PO's en UPO's die noodzakelijk zijn voor de uitvoering van de hun door de gemeenschappelijke marktordening verleende bevoegdheden. In de Basisregeling Producentenorganisaties (PO), Brancheorganisaties (BO) en Verbindend Verklaring (VV) van de RVO van februari $2016^{58}$ wordt over de toepassing van de mededingingsregels op gedragingen van PO's het volgende gezegd:

'Bij erkende PO's is echter een van het algemene mededingingsrecht afwijkend regime van toepassing. Dit brengt mee dat bepaalde afspraken die in het algemeen in andere economische sectoren onder het kartelverbod vallen in de landbouw wel kunnen worden toegestaan bij een PO.'

Deze passage is rijkelijk vaag en geeft geen duiding over de vraag of het om een mededingingsvrije ruimte gaat dan wel om de eventuele uitzondering van artikel 209 van Verordening (EU) nr. 1308/2013. Bij de informatie die bij de erkenningsaanvraag voor een PO moet worden verstrekt staat uitdrukkelijk dat geen activiteiten mogen worden uitgevoerd die leiden tot identieke prijsvorming. Deze passage wijst erop dat de Nederlandse overheid niet uitgaat van een mededingingsvrije ruimte voor PO's. De Basisregeling zal dus gewijzigd moeten worden om haar in overeenstemming te brengen met de uitspraak van het Hof van Justitie.

Ook de ACM heeft zich nog niet uitgesproken over een mededingingsvrije ruimte voor PO's en UPO's. In twee besluiten ${ }^{59}$ heeft zij wel geoordeeld dat bij afwezigheid van een erkenning van een PO of UPO geen beroep gedaan kan worden op het niet van toepassing zijn van artikel 101 lid 1 VWEU op bepaalde overeenkomsten tussen landbouwproducenten of tussen PO's met het argument dat deze overeenkomsten de doelstellingen van het gemeenschappelijk landbouwbeleid zouden nastreven. Deze besluiten zijn in beroep gehandhaafd. ${ }^{60}$

\section{Slot}

Het arrest is een ondersteuning voor het nieuwe landbouwbeleid, dat niet zozeer meer uitgaat van overheidsbemoeiing met het prijs- en hoeveelhedenbeleid, maar erop doelt om de landbouwers meer marktconform te laten opereren. Een belangrijk instrument daarbij zijn de PO's, UPO's en brancheorganisaties, die tot doel hebben om evenwichtiger marktverhoudingen tussen de vraag- en aanbodzijde van de markt tot stand te brengen. Er zijn immers veel, en meestal kleine, producenten aan de aanbodzijde en weinig, en meestal grote afnemers aan de vraagzijde. Het creëren van evenwichtiger marktverhoudingen betekent dat landbouwers ertoe moeten worden aangezet om zich te verenigen in PO's en UPO's om daardoor een sterkere positie tegenover de afnemers te krijgen. Dan moeten de organisaties wel voldoende middelen ter beschikking staan om dit tegengewicht te kunnen bieden. Het arrest van het Hof van Justitie draagt daartoe bij.

58. <www.rvo.nl/sites/default/files/2014/11/ALG\%20basis\%20POs $\% 20 B O s \% 20$ en $\% 20 V$ Vs.februari2016.pdf>

59. Besluit ACM van 15 mei 2012 in zaak 7036, Paprika en Besluit ACM van 25 mei 2012 in zaak 6964, Zilveruien. Zie ook Janssen en Van der Heul, NtEr 2015, p. 168.

60. Rb. Rotterdam 20 maart 2014, ECLI:NL:RBROT:2014:4689 (Paprika) en Rb. Rotterdam 20 maart 2014, ECLI:NL:RBROT:2014:2045 (Zilveruien). Deze laatste uitspraak is bevestigd door CBb 24 maart 2016, ECLI:NL:CBB:2016:56 